\title{
NCDs in Korea and World in the 21st Century
}

\author{
Yong Duk Park \\ Vice-President of Shinhan University, Korea
}

\section{NCDs in Korea}

A non-communicable disease (NCD) is a disease that is not transmissible directly from one person to another. NCDs include Parkinson's disease, autoimmune diseases, strokes, most heart diseases, most cancers, diabetes, chronic kidney disease, osteoarthritis, osteoporosis, Alzheimer's disease, cataracts, and others(table 1). NCDs may be chronic or acute. Most are non-infectious, although there are some non-communicable infectious diseases, such as parasitic diseases in which the parasite's life cycle does not include direct host-to-host transmission. NCDs are very important because they ultimately play an important function, action, and prevention in oral health directly or indirectly. So, I would like to introduce it because it is actively researched on the relationship with oral diseases worldwide.

NCDs change over the past 30 years in Korea(table 2). Again, cancer is the undisputed number one (27.5\%), and the rate is overwhelmingly increasing. There are many different types, but we omit them. The second is vascular disease (24.7\%). In detail, heart disease $10.5 \%$, cerebrovascular disease $7.3 \%$, diabetes $2.7 \%$, Alzheimer's disease $2.3 \%$, and hypertensive disease $1.9 \%$.And the last one is lung disease (10\%), pneumonia $7.9 \%$, and chronic airway disease $2.1 \%$. Lastly, intentional self-harm or suicide (4.7\%).

Table 1. Top 10 specific causes of years of life lost (YLLs) due to premature mortality, years lived with a disability (YLDs), and disability-adjusted life years (DALYs) in 2012 by sex: male cases

\begin{tabular}{|c|c|c|c|c|c|c|}
\hline \multirow{2}{*}{ Specific causes } & \multicolumn{2}{|c|}{ DALYS } & \multicolumn{2}{|c|}{ YLLS } & \multicolumn{2}{|c|}{ YLDs } \\
\hline & Rank & №. $(\%)$ & Rank & №. $(\%)$ & Rank & No. $(\%)$ \\
\hline Diabetes mellitus & 1 & $2,439(12.06)$ & 8 & $161(4.65)$ & 1 & $2,278(13.60)$ \\
\hline Low back pain & 2 & $1,402(6.93)$ & 80 & $0.09(0.003)$ & 2 & $1,401(8.37)$ \\
\hline Cirrhosis of the liver & 3 & $1,262(6.24)$ & 4 & $320(9.22)$ & 4 & $942(5.63)$ \\
\hline Ischemic heart disease & 4 & $1,214(6.01)$ & 1 & $374(10.78)$ & 5 & $841(5.02)$ \\
\hline Chronic obstructive pulmonary disease & 5 & $1,175(5.81)$ & 10 & $106(3.06)$ & 3 & $1,069(6.38)$ \\
\hline Ischemic stroke & 6 & $1,009(4.99)$ & 7 & $195(5.63)$ & 6 & $814(4.86)$ \\
\hline Benign prostatic hyperplasia & 7 & $616(3.05)$ & 81 & $0(0)$ & 7 & $616(3.68)$ \\
\hline Periodontal disease & 8 & $453(2.24)$ & 81 & $0(0)$ & 8 & $453(2.70)$ \\
\hline Trachea, bronchus and lung cancers & 9 & $447(2.21)$ & 3 & $351(10.13)$ & 39 & $96(0.57)$ \\
\hline Liver cancer & 10 & $447(2.21)$ & 2 & $362(10.44)$ & 40 & $85(0.50)$ \\
\hline Asthma & 11 & $436(2.15)$ & 30 & $16(0.45)$ & 9 & $420(2.51)$ \\
\hline Hemorrhagic \& other non-ischemic stroke & 12 & $402(1.99)$ & 5 & $253(7.29)$ & 32 & $149(0.89)$ \\
\hline Stomach cancer & 13 & $399(1.97)$ & 6 & $212(6.11)$ & 27 & $187(1.12)$ \\
\hline Gastroesophageal reflux disease & 14 & $334(1.65)$ & 78 & $0.25(0.01)$ & 10 & $334(1.99)$ \\
\hline Colon and rectum cancers & 15 & $326(1.61)$ & 9 & $158(4.55)$ & 29 & $168(1.00)$ \\
\hline
\end{tabular}

YLLS, YLDs, DALYS per 100,000 males. Sums may not add up to exact total due to rounding.

Copyright (C) 2021. Korean Academy of Preventive Dentistry. All rights reserved.

This is an Open Access article distributed under the terms of the Creative Commons Attribution Non-Commercial License (http:/creativecommons.org/licenses/ by-nc/4.0) which permits unrestricted non-commercial use, distribution, and reproduction in any medium, provided the original work is properly cited. 
Table 2 Changes in 10 causes of death over 30 years

\begin{tabular}{|c|c|c|c|c|c|c|c|c|c|c|}
\hline rank & \multicolumn{3}{|c|}{1989} & \multicolumn{2}{|l|}{1999} & \multicolumn{2}{|l|}{2009} & \multicolumn{3}{|c|}{2019} \\
\hline & $\begin{array}{l}\text { cause of } \\
\text { death }\end{array}$ & $\%$ & $\begin{array}{l}\text { death } \\
\text { rate }\end{array}$ & cause of death & $\begin{array}{l}\text { death } \\
\text { rate }\end{array}$ & $\begin{array}{l}\text { cause of } \\
\text { death }\end{array}$ & $\begin{array}{l}\text { death } \\
\text { rate }\end{array}$ & $\begin{array}{l}\text { cause of } \\
\text { death }\end{array}$ & $\%$ & $\begin{array}{l}\text { death } \\
\text { rate }\end{array}$ \\
\hline 1 & $\begin{array}{l}\text { Malignant } \\
\text { neoplasm }\end{array}$ & 15.8 & 88.2 & $\begin{array}{l}\text { Malignant } \\
\text { neoplasm }\end{array}$ & 114.2 & $\begin{array}{l}\text { Malignant } \\
\text { neoplasm }\end{array}$ & 140.5 & $\begin{array}{l}\text { Malignant } \\
\text { neoplasm }\end{array}$ & 27.5 & 158.2 \\
\hline 2 & $\begin{array}{l}\text { cerebrovascu } \\
\text { lar disease }\end{array}$ & 11.2 & 62.4 & $\begin{array}{l}\text { cerebrovascular } \\
\text { disease }\end{array}$ & 72.9 & $\begin{array}{l}\text { cerebrovascula } \\
\mathrm{r} \text { disease }\end{array}$ & 52.0 & $\begin{array}{l}\text { heart } \\
\text { disease }\end{array}$ & 10.5 & 60.4 \\
\hline 3 & heart disease & 6.9 & 38.6 & heart disease & 38.9 & heart disease & 45.0 & $\begin{array}{l}\text { Pneumoni } \\
\text { a }\end{array}$ & 7.9 & 45.1 \\
\hline 4 & $\begin{array}{l}\text { Hypertensive } \\
\text { disease }\end{array}$ & 5.6 & 31.4 & $\begin{array}{l}\text { transport } \\
\text { accident }\end{array}$ & 26.2 & $\begin{array}{l}\text { Intentional } \\
\text { self-harm }\end{array}$ & 31.0 & $\begin{array}{l}\text { cerebrova } \\
\text { scular } \\
\text { disease } \\
\text { Intentiona }\end{array}$ & 4.7 & 42.0 \\
\hline 5 & liver disease & 5.2 & 29.2 & liver disease & 23.4 & diabetes & 19.6 & $\begin{array}{l}\text { l self-harm } \\
\text { sar }\end{array}$ & 4.7 & 26.9 \\
\hline 6 & $\begin{array}{l}\text { transport } \\
\text { accident }\end{array}$ & 4.9 & 27.3 & diabetes & 21.8 & $\begin{array}{l}\text { transport } \\
\text { accident }\end{array}$ & 14.4 & diabetes & 2.7 & 15.8 \\
\hline 7 & Tuberculosis & 1.9 & 10.7 & $\begin{array}{l}\text { Intentional } \\
\text { self-harm }\end{array}$ & 15.0 & $\begin{array}{l}\text { chronic } \\
\text { respiratory } \\
\text { disease }\end{array}$ & 13.9 & $\begin{array}{l}\text { Alzheimer } \\
\text { 's disease }\end{array}$ & 2.3 & 13.1 \\
\hline 8 & $\begin{array}{l}\text { chronic } \\
\text { respiratory } \\
\text { disease }\end{array}$ & 1.6 & 9.1 & $\begin{array}{l}\text { chronic } \\
\text { respiratory } \\
\text { disease }\end{array}$ & 13.7 & liver disease & 13.8 & $\begin{array}{l}\text { liver } \\
\text { disease }\end{array}$ & 2.2 & 12.7 \\
\hline 9 & diabetes & 1.4 & 7.9 & $\begin{array}{l}\text { Hypertensive } \\
\text { disease }\end{array}$ & 13.7 & Pneumonia & 12.7 & $\begin{array}{l}\text { chronic } \\
\text { respirator } \\
\text { y disease }\end{array}$ & 2.1 & 12.0 \\
\hline 10 & $\begin{array}{l}\text { Intentional } \\
\text { self-harm }\end{array}$ & 1.3 & 7.4 & Pneumonia & 6.7 & $\begin{array}{l}\text { Hypertensive } \\
\text { disease }\end{array}$ & 9.6 & $\begin{array}{l}\text { Hypertens } \\
\text { ive } \\
\text { disease }\end{array}$ & 1.9 & 11.0 \\
\hline
\end{tabular}

\section{WHO suggest and NCDs in the world}

\section{1) Key facts}

Noncommunicable diseases (NCDs) kill 41 million people each year, equivalent to 71\% of all deaths globally. Each year, more than 15 million people die from a NCD between the ages of 30 and 69 years; $85 \%$ of these "premature" deaths occur in low- and middle-income countries. $77 \%$ of all NCD deaths are in low- and middle-income countries. Cardiovascular diseases account for most NCD deaths, or 17.9 million people annually, followed by cancers (9.3 million), respiratory diseases (4.1 million), and diabetes ( 1.5 million). These four groups of diseases account for over $80 \%$ of all premature NCD deaths. Tobacco use, physical inactivity, the harmful use of alcohol and unhealthy diets all increase the risk of dying from a NCD.Detection, screening and treatment of NCDs, as well as palliative care, are key components of the response to NCDs. Noncommunicable diseases (NCDs), also known as chronic diseases, tend to be of long duration and are the result of a combination of genetic, physiological, environmental and behavioural factors.

The main types of NCD are cardiovascular diseases (such as heart attacks and stroke), cancers, chronic respiratory diseases (such as chronic obstructive pulmonary disease and asthma) and diabetes. NCDs disproportionately affect people in low- and middle-income countries where more than three quarters of global NCD deaths - 31.4 million - occur.

\section{2) People at risk of NCDs}

People of all age groups, regions and countries are affected by NCDs. These conditions are often associated with older age groups, but evidence shows that more than 15 million of all deaths attributed to NCDs occur between the ages of 30 and 69 years. Of these "premature" deaths, $85 \%$ are estimated to occur in low- and middle-income countries. Children, adults and the elderly are all vulnerable to the risk factors contributing to NCDs, whether from unhealthy diets, physical inactivity, exposure to tobacco smoke or the harmful use of alcohol. 
These diseases are driven by forces that include rapid unplanned urbanization, globalization of unhealthy lifestyles and population ageing. Unhealthy diets and a lack of physical activity may show up in people as raised blood pressure, increased blood glucose, elevated blood lipids and obesity. These are called metabolic risk factors that can lead to cardiovascular disease, the leading NCD in terms of premature deaths.

\section{3) Risk factors}

(1) Modifiable behaviours, such as tobacco use, physical inactivity, unhealthy diet and the harmful use of alcohol, all increase the risk of NCDs.

Tobacco accounts for over 7.2 million deaths every year (including from the effects of exposure to second-hand smoke), and is projected to increase markedly over the coming years (1).

4.1 million annual deaths have been attributed to excess salt/sodium intake (1). More than half of the 3.3 million annual deaths attributable to alcohol use are from NCDs, including cancer (2).

1.6 million deaths annually can be attributed to insufficient physical activity (1).

(2) Metabolic risk factors contribute to four key metabolic changes that increase the risk of NCDs: raised blood pressure; overweight/obesity; hyperglycemia (high blood glucose levels); and hyperlipidemia (high levels of fat in the blood).

In terms of attributable deaths, the leading metabolic risk factor globally is elevated blood pressure (to which $19 \%$ of global deaths are attributed)(1), followed by overweight and obesity and raised blood glucose.

\section{(3) The socioeconomic impact of NCDs}

NCDs threaten progress towards the 2030 Agenda for Sustainable Development, which includes a target of reducing premature deaths from NCDs by one-third by 2030.

Poverty is closely linked with NCDs. The rapid rise in NCDs is predicted to impede poverty reduction initiatives in low-income countries, particularly by increasing household costs associated with health care. Vulnerable and socially disadvantaged people get sicker and die sooner than people of higher social positions, especially because they are at greater risk of being exposed to harmful products, such as tobacco, or unhealthy dietary practices, and have limited access to health services.

In low-resource settings, health-care costs for NCDs quickly drain household resources. The exorbitant costs of NCDs, including treatment which is often lengthy and expensive, combined with loss of income, force millions of people into poverty annually and stifle development.

\section{4) Prevention and control of NCDs}

An important way to control NCDs is to focus on reducing the risk factors associated with these diseases. Low-cost solutions exist for governments and other stakeholders to reduce the common modifiable risk factors. Monitoring progress and trends of NCDs and their risk is important for guiding policy and priorities.

To lessen the impact of NCDs on individuals and society, a comprehensive approach is needed requiring all sectors, including health, finance, transport, education, agriculture, planning and others, to collaborate to reduce the risks associated with NCDs, and to promote interventions to prevent and control them.

Investing in better management of NCDs is critical. Management of NCDs includes detecting, screening and treating these diseases, and providing access to palliative care for people in need. High impact essential NCD interventions can be delivered through a primary health care approach to strengthen early detection and timely treatment. Evidence shows such interventions are excellent economic investments because, if provided early to patients, they can reduce the need for more expensive treatment.

Countries with inadequate health insurance coverage are unlikely to provide universal access to essential NCD interventions. NCD management interventions are essential for achieving the global target of a $25 \%$ relative reduction in the risk of premature mortality from NCDs by 2025, and the SDG target of a one-third reduction in premature deaths from NCDs by 2030.

\section{5) WHO response}

\section{WHO's leadership and coordination role}

The 2030 Agenda for Sustainable Development recognizes NCDs as a major challenge for sustainable development. As part of the Agenda, Heads of State and Government committed to develop ambitious national responses, by 2030, to reduce by 
one-third premature mortality from NCDs through prevention and treatment (SDG target 3.4). This target comes from the High-level Meetings of the UN General Assembly on NCDs in 2011 and 2014, which reaffirmed WHO's leadership and coordination role in promoting and monitoring global action against NCDs. The UN General Assembly will convene a third High-level Meeting on NCDs in 2018 to review progress and forge consensus on the road ahead covering the period 2018-2030.

To support countries in their national efforts, WHO developed a Global action plan for the prevention and control of NCDs 2013-2020, which includes nine global targets that have the greatest impact on global NCD mortality. These targets address prevention and management of NCDs.

\section{References}

1. GBD 2015 Risk Factors Collaborators. Global, regional, and national comparative risk assessment of 79 behavioural, environmental and occupational, and metabolic risks or clusters of risks, 1990-2015: a systematic analysis for the Global Burden of Disease Study 2015. Lancet, 2016; 388(10053):1659-1724

2. https://www.who.int/news-room/fact-sheets/detail/noncommunicable-diseases

3. Yoon J, et al. Disability-adjusted Life Years for Non-Communicable Diseases in Korea, J Korean Med Sci 2016; 31: S158-167

4. Korea Statistical Office, 2021 